\title{
Optimal Use of Vitamin D When Treating Osteoporosis
}

\author{
Joop P. W. van den Bergh • Sandrine P. G. Bours • \\ Tineke A. C. M. van Geel • Piet P. Geusens
}

Published online: 27 November 2010

(C) The Author(s) 2010. This article is published with open access at Springerlink.com.

\begin{abstract}
Inadequate serum 25-hydroxyvitamin D (25[OH] D) concentrations are associated with muscle weakness, decreased physical performance, and increased propensity in falls and fractures. This paper discusses several aspects with regard to vitamin $\mathrm{D}$ status and supplementation when treating patients with osteoporosis in relation to risks and
\end{abstract}

\section{J. P. W. van den Bergh $(\square)$}

Department of Internal Medicine,

VieCuri Medical Centre Noord-Limburg,

P.O. Box 1926, 5900 BX, Venlo, The Netherlands

e-mail: jvdbergh@hetnet.nl

\section{J. P. W. van den Bergh}

Faculty of Health Medicine and Life Science,

Department of Internal Medicine,

Maastricht University Medical Centre/Nutrim,

P.O. Box 616, 6200 MD, Maastricht, The Netherlands

\section{S. P. G. Bours}

Department of Internal Medicine, Subdivision Endocrinology,

Maastricht University Medical Centre, Maastricht,

P.O. Box 616, 6200 MD, Maastricht, The Netherlands

e-mail: s.bours@mumc.nl

T. A. C. M. van Geel

Faculty of Health Medicine and Life Science,

Department of General Practice,

Maastricht University Medical Centre/Caphri,

P.O. Box 616, 6200 MD, Maastricht, The Netherlands

e-mail: t.laurs-vangeel@hag.unimaas.nl

\section{P. P. Geusens}

Faculty of Health Medicine and Life Science,

Department of Internal Medicine, Maastricht University/Caphri,

P.O. Box 616, 6200 MD, Maastricht, The Netherlands

e-mail: piet.geusens@scarlet.be

\section{P. P. Geusens}

Biomedical Research Center, University Hasselt,

Hasselt, Belgium prevention of falls and fractures. Based on evidence from literature, adequate supplementation with at least $700 \mathrm{IU}$ of vitamin $\mathrm{D}$, preferably cholecalciferol, is required for improving physical function and prevention of falls and fractures. Additional calcium supplementation may be considered when dietary calcium intake is below $700 \mathrm{mg}$ /day. For optimal bone mineral density response in patients treated with antiresorptive or anabolic therapy, adequate vitamin D and calcium supplementation is also necessary. Monitoring of 25(OH)D levels during follow-up and adjustment of vitamin D supplementation should be considered to reach and maintain adequate serum $25(\mathrm{OH}) \mathrm{D}$ levels of at least $50 \mathrm{nmol} / \mathrm{L}$, preferably greater than $75 \mathrm{nmol} / \mathrm{L}$ in all patients.

Keywords Vitamin D · Falls fractures .

Supplementation · 25-hydroxyvitamin D (25[OH]D) · PTH · Neuromuscular function

\section{Introduction}

Osteoporosis is a chronic, progressive disease characterized by reduced bone mass and microarchitectural deterioration of bone, involving an extensive fragility and a subsequent increase in fracture risk [1]. Fracture risk increases with age and is often associated with an increased bone remodeling resulting in bone resorption, loss of bone strength, and decrease of bone mineral density (BMD) [2]. More than $90 \%$ of fractures occur after a fall and fall rates increase with age postural instability and/or quadriceps weakness [3].

Inadequate serum 25-hydroxyvitamin D $(25[\mathrm{OH}] \mathrm{D})$ concentrations are associated with decreased intestinal calcium absorption causing compensatory increase in parathyroid hormone (PTH) levels and thus secondary hyperparathyroidism leading to a lower degree of mineral- 
ization and accelerated bone loss $[4,5]$. Declining vitamin D levels are also associated with muscle weakness, decreased balance and physical performance, and increased propensity in falls and fractures [6-8]. Vitamin D insufficiency has now been linked to a broad spectrum of human diseases from cancer to cardiovascular to autoimmune conditions, but these topics are out of the scope of this paper [9]. In this paper we discuss several aspects with regard to vitamin D status and supplementation when treating osteoporosis in relation to risks and prevention of falls and fractures based on a number of recently published meta-analyses.

\section{Vitamin D Status}

The stages of vitamin D deficiency are generally defined based on circulating $25(\mathrm{OH}) \mathrm{D}$ levels, in which a serum level less than $12.5 \mathrm{nmol} / \mathrm{L}$ is defined as severe deficiency, a level between 12.5 and $25 \mathrm{nmol} / \mathrm{L}$ as deficiency, and a level of 25 to $50 \mathrm{nmol} / \mathrm{L}$ as vitamin D insufficiency [5]. The 1,25-dihydroxyvitamin $\mathrm{D}$ assay should not be used for detecting vitamin $\mathrm{D}$ deficiency because levels will be normal or even elevated as a result of secondary hyperparathyroidism [10]. Several end points can be used for defining optimal vitamin $\mathrm{D}$ status in terms of $25(\mathrm{OH}) \mathrm{D}$ levels: prevention of PTH elevation, optimal muscle function, prevention of bone loss, falls or fractures.

\section{Relationship Between 25(OH)D and PTH Levels and Vitamin D Supplementation}

PTH is secreted in response to reduced calcium levels causing an increase in bone resorption and subsequently normalization of calcium levels. In case of vitamin D deficiency, secondary hyperparathyroidism results in increased bone turnover and bone loss and may subsequently increase fracture risk [5]. The relationship between $25(\mathrm{OH})$ $\mathrm{D}$ and PTH levels has been described in several crosssectional studies, indicating a significant negative correlation between PTH and 25(OH)D values with only a minimal increase of PTH when serum $25(\mathrm{OH}) \mathrm{D}$ is above 50 to $75 \mathrm{nmol} / \mathrm{L}[11,12,13 \cdot, 14]$. Recently, Carnevale et al. [14] demonstrated that PTH levels were mainly determined by $25(\mathrm{OH}) \mathrm{D}$ levels up to $40 \mathrm{nmol} / \mathrm{L}$ and to serum ionized calcium at levels greater than $40 \mathrm{nmol} / \mathrm{L}$ in healthy volunteers. In a recent study it has been shown that for the same 25-OHD level, PTH levels were comparable across genders but were 1.5- to twofold higher in the elderly compared with adolescents [15] and that elevated PTH is a strong independent predictor for poor outcomes in older patients $[16,17]$.
Vitamin $\mathrm{D}_{3}$ supplementation (cholecalciferol) with a dose of $600 \mathrm{IU} /$ day during 4 months decreased median serum PTH levels by $23 \%$ in elderly nursing home residents who had mean baseline 25(OH)D levels of $25.0 \mathrm{nmol} / \mathrm{L}$. Calcium supplementation had no effect on serum PTH [18]. In osteoporosis patients, 25(OH)D increased and PTH decreased more in those taking $3000 \mathrm{IU}$ of vitamin $\mathrm{D}$ per day compared with $800 \mathrm{IU} /$ day. An increase of $25(\mathrm{OH}) \mathrm{D} \geq 75 \mathrm{nmol} / \mathrm{L}$ resulted in normalized PTH [19]. In contrast, in healthy men and women between 20 and 80 years with a baseline 25 $(\mathrm{OH}) \mathrm{D}$ level of $67 \mathrm{nmol} / \mathrm{L}$, acute ingestion of a $600-\mathrm{mg}$ calcium carbonate lowered PTH and bone turnover markers, whereas additional intake of $4000 \mathrm{IU} /$ day of vitamin $\mathrm{D}_{3}$ did not lower PTH or markers of bone turnover [20]. This is in line with previous findings that PTH levels do not decrease after vitamin D supplementation [21] or only marginally decreased after vitamin $\mathrm{D}$ and calcium supplementation in subjects with baseline $25(\mathrm{OH}) \mathrm{D}$ levels $\geq 50 \mathrm{nmol} / \mathrm{L}$ [22]. From these data it seems apparent that vitamin D supplementation decreases PTH levels up to a $25(\mathrm{OH}) \mathrm{D}$ level of $50 \mathrm{nmol} / \mathrm{L}$ and that calcium supplementation might additionally lower PTH when $25(\mathrm{OH}) \mathrm{D}$ is $\geq 50 \mathrm{nmol} / \mathrm{L}$.

\section{Relationship Between 25(OH)D Levels, Neuromuscular Function, and Vitamin D Supplementation}

The nuclear receptor for vitamin D (VDR) is expressed in many human cell types, including muscle cells $[10,23]$. Older age is associated with decreased VDR expression, independent of serum 25(OH)D levels [24]. The effect of vitamin $\mathrm{D}$ on muscle tissue is thought to occur through specific VDRs. Cross-sectional studies show that elderly people with deficient $25(\mathrm{OH}) \mathrm{D}$ serum levels have muscle weakness, particularly in proximal muscles, associated to a decrease in motion ability and capabilities, which increases the number of falls $[25,26]$. A serum 25(OH)D level below $50 \mathrm{nmol} / \mathrm{L}$ is associated with increased body sway and a level below $30 \mathrm{nmol} / \mathrm{L}$ with decreased muscle strength [27]. In a prospective, population-based study, Visser et al. [28] showed that low 25(OH)D levels and high PTH levels increased the risk of sarcopenia in subjects 65 years of age or older. In both active and inactive ambulatory persons aged $\geq 60$ years of age, $25(\mathrm{OH}) \mathrm{D}$ concentrations $\geq 40 \mathrm{nmol} /$ $\mathrm{L}$ were associated with better musculoskeletal function in the lower extremities than concentrations less than $40 \mathrm{nmol} /$ $\mathrm{L}$ [29] and in serum 25(OH)D concentrations below $50 \mathrm{nmol} / \mathrm{L}$ were associated with poorer physical performance and a greater decline in physical performance in men and women $\geq 65$ years of age [7]. In randomized controlled trials (RCTs), vitamin D supplementation increased muscle strength and balance with $800 \mathrm{IU}$ of vitamin D on top of calcium substitution $[30,31]$. However, in a recent study by 
Lips et al. [32], weekly treatment with 8400 IU of vitamin D did not reduce mediolateral sway significantly compared with treatment with placebo in subjects $\geq 70$ years of age, with serum 25(OH)D levels between 15 and $50 \mathrm{nmol} / \mathrm{L}$, although in post hoc analysis, treatment with $8400 \mathrm{IU}$ of vitamin D per week reduced sway in the subgroup of patients who had elevated sway at baseline. Based on these results it seems likely that vitamin D substitution improves physical performance and that those with severe vitamin D deficiency experience the greatest benefit.

\section{Relationship Between 25(OH)D Levels, Risk of Falling, and Vitamin D Supplementation}

A beneficial effect of vitamin $\mathrm{D}$ supplementation on fall prevention among ambulatory or institutionalized older individuals with stable health by more than $20 \%$ was suggested by the meta-analysis of Bischoff-Ferrari et al. [33]. This metaanalysis was based on five RCTs involving 1237 participants treated with cholecalciferol or active vitamin $\mathrm{D}$ analogues compared with patients receiving calcium or placebo. The benefit was most clearly established for women and with active vitamin D analogues [33]. Active forms of vitamin D do not need hydroxylation in the kidney, so their effect on falls should be influenced less by age-related decline in kidney function than the effect of supplemental vitamin D. In 2008 one meta-analysis showed that active vitamin D supplementation seemed to prevent falls to a greater extent than their native compound [34] and in another small metaanalysis with combined data of two trials a significant risk reduction of falls was also demonstrated [35].

In a more recent meta-analysis the efficacy of vitamin D supplementation was assessed for the prevention of falls among older persons by dose and serum concentration of $25(\mathrm{OH}) \mathrm{D}$ achieved [36]. In this analysis 10 RCTS trials were included: three with ergocalciferol, five with cholecalciferol, and two with active forms of vitamin D doses (one with alfacalcidol and one with calcitriol). Dosages of supplemental vitamin D of 700 to $1000 \mathrm{IU} /$ day could reduce falls by $19 \%$ or by up to $26 \%$ with ergocalciferol, independent of additional calcium supplementation. Vitamin D doses below $700 \mathrm{IU}$ a day did not prevent falls. A 25 $(\mathrm{OH}) \mathrm{D}$ concentration of at least $60 \mathrm{nmol} / \mathrm{L}$ was required for fall prevention. From this analysis it seems likely that greater benefits may be achieved with vitamin $\mathrm{D}_{3}$ instead of vitamin $\mathrm{D}_{2}$. Active forms of vitamin $\mathrm{D}$ do not appear to be more effective than 700 to $1000 \mathrm{IU}$ of vitamin D for fall prevention in this analysis [36].

In the Cochrane review of interventions for preventing falls in older people living in the community, the efficacy for fall prevention of supplementation with vitamin D or an analogue, either alone or with calcium co-supplementation, was analyzed [37]. The overall analysis of vitamin D versus control did not show a statistically significant difference in rate of falls or risk of falling in 10 studies with 21,110 participants. In a post hoc subgroup analysis the rate of falls was significantly reduced in trials recruiting participants with lower $(<50 \mathrm{nmol} / \mathrm{L})$ baseline $25(\mathrm{OH}) \mathrm{D}$ levels (relative risk [RR], 0.57 ; $95 \%$ CI, $0.37-0.89$ in 260 participants, two trials) but not in participants not so selected (RR, 1.02; 95\% CI, $0.88-1.19$ in 3669 participants, three trials). For calcitriol but not alfacalcidol a significant reduction in rate of falls and risk of falling was reported; however, there was also a significant increase in the risk of hypercalcemia [37].

The Cochrane review of interventions for preventing falls in older people in nursing care facilities and hospitals reported a significant reduction of the rate of falls (RR, $0.72 ; 95 \%$ CI, 0.55-0.95, 4512 participants in four trials; one with cholecalciferol and three with ergocalciferol), although the number of fallers was not significantly different (RR, 0.98; 95\% CI, 0.89-1.09, 5095 participants in five trials; two with cholecalciferol and three with ergocalciferol) with vitamin D supplementation compared with placebo or calcium in nursing care facilities [38]. Average serum 25(OH)D levels were between 22 and $47 \mathrm{nmol} / \mathrm{L}$ in the included studies. Caution may be required with interpretation of these pooled data because of statistical and clinical heterogeneity.

In the most recent review including 10 RCTs, vitamin D treatment effectively reduced the risk of falls with $14 \%$ in community dwelling and institutionalized older adults with a mean age from 71 to 92 years [39]. Three types of vitamin D (six studies with cholecalciferol, three with ergocalciferol, and one with alfacalcidol) were used. In seven studies patients used additional calcium therapy and in three studies no additional medication was used. Treatment duration ranged between 1 and 36 months, and native vitamin D dosage ranged between 200 and 1000 IU. The effect of vitamin $\mathrm{D}$ on fall reduction was significant in several subgroups of individuals: mean age younger than 80 years, additional calcium therapy, no history of fracture or fall, dose of $800 \mathrm{IU}$ or greater, cholecalciferol therapy, duration of treatment longer than 6 months, although no evidence was found of a relationship between higher doses of vitamin D or longer duration of vitamin D therapy and treatment effect [39]. It has to be noted that all studies included in the meta-analysis had populations with $25(\mathrm{OH})$ D levels less than $75 \mathrm{nmol} / \mathrm{L}$.

\section{Relationship Between 25(OH)D Levels, Risk of Fractures, and Vitamin D Supplementation}

During the past years several meta-analysis have been published on the effect of vitamin $\mathrm{D}$ with and without 
calcium with fracture incidence as outcome criterion [40$42,43 \bullet \bullet, 44 \bullet \bullet, 45,46 \bullet \cdot$. The analysis of Bischoff-Ferrari et al. [40], including five RCTs for hip fracture $(n=9294)$ and seven RCTs for nonvertebral fracture risk $(n=9820)$, concluded that vitamin D dose of 700 to $800 \mathrm{IU} /$ day reduced the relative risk of hip fracture by $26 \%$ (three RCTs with 5572 persons; pooled RR, 0.74; 95\% CI, 0.61-0.88) and of any nonvertebral fracture by $23 \%$ (five RCTs with 6098 persons; pooled RR, 0.77 ; 95\% CI, 0.68-0.87) versus calcium or placebo in individuals $\geq 60$ years of age. No significant benefit was observed for RCTs with 400 IU/day of vitamin D (two RCTs with 3722 persons) [40]. The meta-analysis by Boonen et al. [41], designed to extend the findings of Bischoff-Ferrari et al. [40], suggested that only vitamin $\mathrm{D}$ with additional calcium demonstrated a significant reduction of hip and nonvertebral fractures versus placebo or no treatment. A total of 53,260 patients from nine RCTs were included in this analysis and all RCTs used cholecalciferol with a dose of 700 to $800 \mathrm{IU} /$ day in six trials and $400 \mathrm{IU} /$ day in the other three trials. Calcium (500$1200 \mathrm{mg} / \mathrm{d}$ ) was given with vitamin D in six RCTs. In an adjusted indirect comparison further support was found for combined supplementation of vitamin D and calcium, with a $25 \%$ reduction in hip fracture risk compared with vitamin $\mathrm{D}$ alone and it was suggested that oral vitamin $\mathrm{D}$ appears to reduce the risk of hip fractures only when calcium supplementation is added [41]. It has to be noted that two trials with very low nutritional baseline calcium intake had an important impact on the results of this meta-analysis [47, 48].

The meta-analysis of Tang et al. [42] showed that calcium supplementation, alone or in combination with vitamin $\mathrm{D}$, was effective in the preventive treatment of osteoporotic fracture. The fracture risk reduction was greater in individuals who were elderly, living in institutions, and had a low baseline calcium intake. Treatment was similarly effective whether persons used calcium or calcium in combination with vitamin D supplementation. However, the treatment was less effective if compliance was lower than $80 \%$. For calcium-only supplementation, a minimum dose of $1200 \mathrm{mg}$ was needed for best therapeutic effect. For calcium in combination with vitamin D supplementation, a minimum dose of 800 IU of vitamin D was recommended. There was no significant difference in fracture reduction between low versus normal 25(OH)D serum concentration at baseline [42].

In the more recent analysis by Bischoff-Ferrari [43••], which included 12 RCTs for nonvertebral fractures (two with ergocalciferol, 10 with cholecalciferol; $n=42,279)$ and eight RCTs for hip fractures $(n=40,886)$ in individuals 65 years or older, the antifracture efficacy of supplemental vitamin D increased significantly with higher received dose or higher achieved 25(OH)D levels $(>75 \mathrm{nmol} / \mathrm{L}$ ) for any nonvertebral fractures and for hip fractures. No fracture reduction was observed for a dose of 400 IU/day or less, whereas a higher dose of 482 to 770 IU/day of supplemental vitamin D reduced nonvertebral fractures by $20 \%$ and hip fractures by $18 \%$. Subgroup analyses for the prevention of nonvertebral fractures with the higher received dose suggested possibly better fracture reduction with cholecalciferol compared with ergocalciferol, whereas additional calcium did not further improve antifracture efficacy [43••]. The analysis by Bergman et al. [45] supports the use of cholecalciferol 800 IU daily to reduce the incidence of osteoporotic nonvertebral, hip, and nonvertebral-non-hip fractures in women over 50 years of age. In this study, cholecalciferol with calcium appears to achieve benefits above those attained with calcium supplementation alone for nonvertebral and nonvertebral-non-hip fractures [45].

The Cochrane meta-analysis suggested that vitamin D alone appeared unlikely to be effective in preventing hip fracture (nine trials, 24,749 participants; RR, 1.15; 95\% CI, 0.99-1.33), vertebral fracture (five trials, 9138 participants; RR, $0.90 ; 95 \% \mathrm{CI}, 0.42-1.92)$, or any new fracture (10 trials, 25,016 participants; RR, 1.01; 95\% CI, 0.93-1.09). Vitamin D with calcium reduced hip fractures (eight trials, 46,658 participants; RR, 0.84; 95\% CI, 0.73-0.96) [44••].

In the most recent meta-analysis by the DIPART (Vitamin D Individual Patient Analysis of Randomized Trials) group, seven major randomized trials of vitamin D with calcium or vitamin $\mathrm{D}$ alone, with a total of 68,517 participants (mean age 69.9 years; range 47-107 years; $14.7 \%$ men) were included [ $46 \cdot \bullet]$. In this analysis based on individual patient data analysis it was also indicated that vitamin $\mathrm{D}$ with calcium showed a reduced overall risk of fracture (hazard ratio [HR], $0.92 ; 95 \% \mathrm{CI}, 0.86-0.99 ; P=$ 0.025 ) and hip fracture (all studies: $0.84,0.70-1.01 ; P=$ 0.07 ; studies using $400 \mathrm{IU}$ of vitamin $\mathrm{D}$ per day given with calcium: $0.74,0.60-0.91 ; P=0.005)$. Vitamin $\mathrm{D}$ given alone in doses of 400 to $800 \mathrm{IU}$ per day was not effective in preventing fractures $[46 \bullet \cdot]$.

Supplementation with high-dose vitamin D supplementation annually could be harmful. Among 2256 older community-dwelling women, annual oral administration of $500,000 \mathrm{IU}$ of cholecalciferol resulted in an increased risk of falls and fractures compared with placebo [49•]. An annual intramuscular injection of 300,000 IU of ergocalciferol was not effective in preventing nonvertebral fractures among 9440 elderly men and women residents in the general population. The HR for hip fracture was significantly increased (HR, 1.49; 95\% CI, 1.02-2.18) [50].

\section{Optimal Vitamin D Dose for Reduction of Falls and Fractures}

It seems likely that vitamin D substitution improves physical performance and that elderly and those with severe 
vitamin D deficiency experience the greatest benefit. Based on evidence from RCTs and the meta-analyses, vitamin D supplementation reduces both falls and fractures. The beneficial effect of vitamin $\mathrm{D}$ is dose dependent and mainly demonstrated for cholecalciferol with a dose of at least $700 \mathrm{IU} /$ day. Active vitamin D is not preferred because of the increased risk of hypercalcemia.

Annually high-dose vitamin D supplementation could possibly increase fall and fracture risk. It was suggested that a $25(\mathrm{OH}) \mathrm{D}$ concentration of at least $60 \mathrm{nmol} / \mathrm{L}$ was required for fall prevention and optimal fracture prevention appeared to occur in trials with achieved mean 25(OH)D levels of approximately 75 to $100 \mathrm{nmol} / \mathrm{L}$. Additionally, adequate 25(OH)D levels were required for an optimal BMD response in patients who are being treated with bisphosphonates for osteoporosis [51], and coadministration of cholecalciferol and calcium vitamin $\mathrm{D}$ with antiresorptive medication improved the subsequent BMD response unaffected by vitamin $\mathrm{D}$ status at initiation [52, 53]. However, the practical clinical question is whether all treated patients will receive a $25(\mathrm{OH}) \mathrm{D}$ level greater than $60 \mathrm{nmol} / \mathrm{L}$ with a vitamin D dose of 700 or $800 \mathrm{IU} /$ day and if not, what vitamin D intake is needed to achieve serum concentrations greater than $60 \mathrm{nmol} / \mathrm{L}$. It has been reported that the rate of increase of $25(\mathrm{OH}) \mathrm{D}$ levels was between 0.6 and $1.2 \mathrm{nmol} / \mathrm{L}$ per $40 \mathrm{IU}$ daily of vitamin $\mathrm{D}_{3}$ and that the response may well be an inverse function of the starting 25 $(\mathrm{OH}) \mathrm{D}$ concentration [54]. Seasonal fluctuations on $25(\mathrm{OH})$ D levels may further contribute to insufficient vitamin D status during winter months, especially in the elderly [55]. Based on these aspects it seems warranted to measure a baseline $25(\mathrm{OH}) \mathrm{D}$ level in all patients who are going to be treated with antiosteoporosis medication such as patients with a fracture or low bone mass, and to monitor 25(OH)D levels during follow-up and to adjust vitamin D supplementation when desired 25(OH)D levels are not achieved. In patients with severe vitamin D deficiency supplementation may be started with cholecalciferol 20,000 to $50,000 \mathrm{IU} /$ week orally for 3 months until $25(\mathrm{OH}) \mathrm{D}$ levels are at least $50 \mathrm{nmol} / \mathrm{L}$, followed by a daily dose of at least 700 IU. Higher dosages may be necessary when desired 25 $(\mathrm{OH}) \mathrm{D}$ levels are not maintained $[19,56]$.

In addition to vitamin $\mathrm{D}$ status, calcium balance must be optimized. For persons older than 50 years, a total calcium intake of 1000 to $1200 \mathrm{mg}$ per day was advised [57]. Calcium supplementation may be needed when dietary calcium intake is insufficient, although a calcium intake greater than $700 \mathrm{mg}$ /day may be only beneficial for better BMD when 25(OH)D levels are less than $50 \mathrm{nmol} / \mathrm{L}\left[58^{\bullet}\right]$. The meta-analysis by Bischoff-Ferrari et al. [59] showed no reduction in hip fracture risk with calcium supplementation. In addition, recent publications suggest an increased risk of myocardial infarction with calcium supplementation with- out coadministration of vitamin D [60]. However, the risk of myocardial infarction was not increased in people with dietary calcium intake below a median dietary calcium intake of $805 \mathrm{mg} /$ day [60]. Thus, calcium supplementation may be considered when dietary calcium intake is below $700 \mathrm{mg} /$ day, with a calcium supplementation dose that leads to a maximum total daily calcium intake of 1000 to $1200 \mathrm{mg}$.

\section{Conclusions}

Poor vitamin D status and low calcium intake are important determinates for osteoporosis and fracture risk. Based on evidence from literature, adequate supplementation with at least $700 \mathrm{IU}$ of vitamin D, preferably cholecalciferol, is required for improving physical function and prevention of falls and fractures. Additional calcium supplementation may be considered when dietary calcium intake is below $700 \mathrm{mg} /$ day, with a supplementation dose that leads to a maximum total daily calcium intake of 1000 to $1200 \mathrm{mg}$. For optimal BMD response in patients treated with antiresorptive or anabolic therapy, adequate vitamin $\mathrm{D}$ and calcium supplementation is also necessary. It should be considered to monitor 25(OH)D levels during follow-up of patients with osteoporosis to warrant adequate vitamin $\mathrm{D}$ status during treatment and if necessary adjust the vitamin D supplementation dose to reach or maintain $25(\mathrm{OH}) \mathrm{D}$ levels of at least $50 \mathrm{nmol} / \mathrm{L}$, preferably greater than $75 \mathrm{nmol} / \mathrm{L}$ in all patients.

Disclosure No potential conflicts of interest relevant to this article were reported.

Open Access This article is distributed under the terms of the Creative Commons Attribution Noncommercial License which permits any noncommercial use, distribution, and reproduction in any medium, provided the original author(s) and source are credited.

\section{References}

Papers of particular interest, published recently, have been highlighted as:

- Of importance

•• Of major importance

1. Osteoporosis prevention, diagnosis, and therapy. JAMA 2001, 285(6):785-795.

2. Bauer DC, Sklarin PM, Stone KL, Black DM, Nevitt MC, Ensrud $\mathrm{KE}$, Arnaud CD, Genant HK, Garnero P, Delmas PD et al: Biochemical markers of bone turnover and prediction of hip bone loss in older women: the study of osteoporotic fractures. J Bone Miner Res 1999, 14(8):1404-1410. 
3. Nguyen ND, Pongchaiyakul C, Center JR, Eisman JA, Nguyen TV: Identification of high-risk individuals for hip fracture: a 14-year prospective study. J Bone Miner Res 2005, 20(11):1921-1928.

4. Quesada JM, Coopmans W, Ruiz B, Aljama P, Jans I, Bouillon R: Influence of vitamin D on parathyroid function in the elderly. J Clin Endocrinol Metab 1992, 75(2):494-501.

5. Lips P: Vitamin D deficiency and secondary hyperparathyroidism in the elderly: consequences for bone loss and fractures and therapeutic implications. Endocr Rev 2001, 22(4):477-501.

6. Snijder MB, van Schoor NM, Pluijm SM, van Dam RM, Visser M, Lips P: Vitamin D status in relation to one-year risk of recurrent falling in older men and women. J Clin Endocrinol Metab 2006, 91(8):2980-2985.

7. Wicherts IS, van Schoor NM, Boeke AJ, Visser M, Deeg DJ, Smit J, Knol DL, Lips P: Vitamin D status predicts physical performance and its decline in older persons. J Clin Endocrinol Metab 2007, 92(6):2058-2065.

8. van Schoor NM, Visser M, Pluijm SM, Kuchuk N, Smit JH, Lips P: Vitamin D deficiency as a risk factor for osteoporotic fractures. Bone 2008, 42(2):260-266.

9. LaCroix AZ, Kotchen J, Anderson G, Brzyski R, Cauley JA, Cummings SR, Gass M, Johnson KC, Ko M, Larson J et al: Calcium plus vitamin D supplementation and mortality in postmenopausal women: the Women's Health Initiative calciumvitamin D randomized controlled trial. J Gerontol A Biol Sci Med Sci 2009, 64(5):559-567.

10. Holick MF: Vitamin D deficiency. N Engl J Med 2007, 357 (3):266-281.

11. Chapuy MC, Preziosi P, Maamer M, Arnaud S, Galan P, Hercberg S, Meunier PJ: Prevalence of vitamin D insufficiency in an adult normal population. Osteoporos Int 1997, 7(5):439-443.

12. Holick MF, Siris ES, Binkley N, Beard MK, Khan A, Katzer JT, Petruschke RA, Chen E, de Papp AE: Prevalence of Vitamin D inadequacy among postmenopausal North American women receiving osteoporosis therapy. J Clin Endocrinol Metab 2005, 90(6):3215-3224

13. - Kuchuk NO, Pluijm SM, van Schoor NM, Looman CW, Smit JH, Lips P: Relationships of serum 25-hydroxyvitamin D to bone mineral density and serum parathyroid hormone and markers of bone turnover in older persons. J Clin Endocrinol Metab 2009, 94 (4):1244-1250. This study shows that bone health and physical performance in older persons are likely to improve when serum 25 $(\mathrm{OH}) \mathrm{D}$ is raised.

14. Carnevale V, Nieddu L, Romagnoli E, Battista C, Mascia ML, Chiodini I, Eller-Vainicher C, Frusciante V, Santini SA, La Porta $\mathrm{M}$ et al: Regulation of PTH secretion by 25 -hydroxyvitamin D and ionized calcium depends on vitamin D status: a study in a large cohort of healthy subjects. Bone 2010, 47(3):626-630.

15. Arabi A, Baddoura R, El-Rassi R, El-Hajj Fuleihan G: Age but not gender modulates the relationship between PTH and vitamin D. Bone 2010, 47(2):408-412.

16. Fisher A, Goh S, Srikusalanukul W, Davis M: Elevated serum PTH is independently associated with poor outcomes in older patients with hip fracture and vitamin D inadequacy. Calcif Tissue Int 2009, 85(4):301-309.

17. Fisher AA, Southcott EK, Srikusalanukul W, Davis MW, Hickman PE, Potter JM, Smith PN: Relationships between myocardial injury, all-cause mortality, vitamin D, PTH, and biochemical bone turnover markers in older patients with hip fractures. Ann Clin Lab Sci 2007, 37(3):222-232.

18. Chel V, Wijnhoven HA, Smit JH, Ooms M, Lips P: Efficacy of different doses and time intervals of oral vitamin D supplementation with or without calcium in elderly nursing home residents. Osteoporos Int 2008, 19(5):663-671.

19. Leidig-Bruckner G, Roth HJ, Bruckner T, Lorenz A, Raue F, FrankRaue K: Are commonly recommended dosages for vitamin D supplementation too low? Vitamin D status and effects of supplementation on serum 25-hydroxyvitamin D levels-an observational study during clinical practice conditions. Osteoporos Int 2010.

20. Aloia J, Bojadzievski T, Yusupov E, Shahzad G, Pollack S, Mikhail M, Yeh J: The relative influence of calcium intake and vitamin $\mathrm{D}$ status on serum parathyroid hormone and bone turnover biomarkers in a double-blind, placebo-controlled parallel group, longitudinal factorial design. J Clin Endocrinol Metab 2010, 95(7):3216-3224.

21. Malabanan A, Veronikis IE, Holick MF: Redefining vitamin D insufficiency. Lancet 1998, 351(9105):805-806.

22. Lips P, Duong T, Oleksik A, Black D, Cummings S, Cox D, Nickelsen T: A global study of vitamin D status and parathyroid function in postmenopausal women with osteoporosis: baseline data from the multiple outcomes of raloxifene evaluation clinical trial. J Clin Endocrinol Metab 2001, 86(3):1212-1221.

23. Bischoff HA, Borchers M, Gudat F, Duermueller U, Theiler R, Stahelin HB, Dick W: In situ detection of 1,25-dihydroxyvitamin D3 receptor in human skeletal muscle tissue. Histochem J 2001, 33(1):19-24.

24. Bischoff-Ferrari HA, Borchers M, Gudat F, Durmuller U, Stahelin HB, Dick W: Vitamin D receptor expression in human muscle tissue decreases with age. J Bone Miner Res 2004, 19(2):265269.

25. Janssen HC, Samson MM, Verhaar HJ: Vitamin D deficiency, muscle function, and falls in elderly people. Am J Clin Nutr 2002, 75(4):611-615.

26. Dhesi JK, Bearne LM, Moniz C, Hurley MV, Jackson SH, Swift CG, Allain TJ: Neuromuscular and psychomotor function in elderly subjects who fall and the relationship with vitamin D status. J Bone Miner Res 2002, 17(5):891-897.

27. Pfeifer M, Begerow B, Minne HW: Vitamin D and muscle function. Osteoporos Int 2002, 13(3):187-194.

28. Visser M, Deeg DJ, Lips P: Low vitamin D and high parathyroid hormone levels as determinants of loss of muscle strength and muscle mass (sarcopenia): the Longitudinal Aging Study Amsterdam. J Clin Endocrinol Metab 2003, 88(12):5766-5772.

29. Bischoff-Ferrari HA, Dietrich T, Orav EJ, Hu FB, Zhang Y, Karlson EW, Dawson-Hughes B: Higher 25-hydroxyvitamin D concentrations are associated with better lower-extremity function in both active and inactive persons aged $>$ or $=60 \mathrm{y}$. Am J Clin Nutr 2004, 80(3):752-758.

30. Pfeifer M, Begerow B, Minne HW, Suppan K, Fahrleitner-Pammer A, Dobnig H: Effects of a long-term vitamin D and calcium supplementation on falls and parameters of muscle function in community-dwelling older individuals. Osteoporos Int 2009, 20 (2):315-322.

31. Bischoff HA, Stahelin HB, Dick W, Akos R, Knecht M, Salis C, Nebiker M, Theiler R, Pfeifer M, Begerow B et al: Effects of vitamin $\mathrm{D}$ and calcium supplementation on falls: a randomized controlled trial. J Bone Miner Res 2003, 18(2):343-351.

32. Lips P, Binkley N, Pfeifer M, Recker R, Samanta S, Cohn DA, Chandler J, Rosenberg E, Papanicolaou DA: Once-weekly dose of 8400 IU vitamin $\mathrm{D}(3)$ compared with placebo: effects on neuromuscular function and tolerability in older adults with vitamin D insufficiency. Am J Clin Nutr 2010, 91(4):985-991.

33. Bischoff-Ferrari HA, Dawson-Hughes B, Willett WC, Staehelin HB, Bazemore MG, Zee RY, Wong JB: Effect of Vitamin D on falls: a meta-analysis. JAMA 2004, 291(16):1999-2006.

34. Richy F, Dukas L, Schacht E: Differential effects of D-hormone analogs and native vitamin $\mathrm{D}$ on the risk of falls: a comparative meta-analysis. Calcif Tissue Int 2008, 82(2):102-107.

35. O'Donnell S, Moher D, Thomas K, Hanley DA, Cranney A: Systematic review of the benefits and harms of calcitriol and alfacalcidol for fractures and falls. J Bone Miner Metab 2008, 26 (6):531-542. 
36. Bischoff-Ferrari HA, Dawson-Hughes B, Staehelin HB, Orav JE, Stuck AE, Theiler R, Wong JB, Egli A, Kiel DP, Henschkowski J: Fall prevention with supplemental and active forms of vitamin D: a meta-analysis of randomised controlled trials. BMJ 2009, 339:b3692.

37. Gillespie LD, Robertson MC, Gillespie WJ, Lamb SE, Gates S, Cumming RG, Rowe BH: Interventions for preventing falls in older people living in the community. Cochrane Database Syst Rev 2009(2):CD007146.

38. Cameron ID, Murray GR, Gillespie LD, Robertson MC, Hill KD, Cumming RG, Kerse N: Interventions for preventing falls in older people in nursing care facilities and hospitals. Cochrane Database Syst Rev 2010(1):CD005465.

39. Kalyani RR, Stein B, Valiyil R, Manno R, Maynard JW, Crews DC: Vitamin D treatment for the prevention of falls in older adults: systematic review and meta-analysis. J Am Geriatr Soc 2010, 58(7):1299-1310.

40. Bischoff-Ferrari HA, Willett WC, Wong JB, Giovannucci E, Dietrich T, Dawson-Hughes B: Fracture prevention with vitamin D supplementation: a meta-analysis of randomized controlled trials. JAMA 2005, 293(18):2257-2264.

41. Boonen S, Lips P, Bouillon R, Bischoff-Ferrari HA, Vanderschueren D, Haentjens P: Need for additional calcium to reduce the risk of hip fracture with vitamin d supplementation: evidence from a comparative metaanalysis of randomized controlled trials. J Clin Endocrinol Metab 2007, 92(4):1415-1423.

42. Tang BM, Eslick GD, Nowson C, Smith C, Bensoussan A: Use of calcium or calcium in combination with vitamin $\mathrm{D}$ supplementation to prevent fractures and bone loss in people aged 50 years and older: a meta-analysis. Lancet 2007, 370(9588):657-666.

43. - Bischoff-Ferrari HA, Willett WC, Wong JB, Stuck AE, Staehelin HB, Orav EJ, Thoma A, Kiel DP, Henschkowski J: Prevention of nonvertebral fractures with oral vitamin $\mathrm{D}$ and dose dependency: a meta-analysis of randomized controlled trials. Arch Intern Med 2009, 169(6):551-561. This is an important recent meta-analysis with regard to fracture prevemtion with vitamin $D$ and the dose dependency.

44. •• Avenell A, Gillespie WJ, Gillespie LD, O'Connell D: Vitamin $\mathrm{D}$ and vitamin $\mathrm{D}$ analogues for preventing fractures associated with involutional and post-menopausal osteoporosis. Cochrane Database Syst Rev 2009(2):CD000227. In this Cochrane review the effect of vitamin $D$ on prevention of fractures is extensively analyzed.

45. Bergman GJ, Fan T, McFetridge JT, Sen SS: Efficacy of vitamin D3 supplementation in preventing fractures in elderly women: a meta-analysis. Curr Med Res Opin 2010, 26(5):1193-1201.

46. •- Patient level pooled analysis of 68500 patients from seven major vitamin D fracture trials in US and Europe. BMJ 2010, 340: b5463. This is another important recently published pooled analysis with regard to fracture prevention with vitamin $D$.

47. Chapuy MC, Arlot ME, Duboeuf F, Brun J, Crouzet B, Arnaud S, Delmas PD, Meunier PJ: Vitamin D3 and calcium to prevent hip fractures in the elderly women. N Engl J Med 1992, 327 (23):1637-1642.

48. Chapuy MC, Pamphile R, Paris E, Kempf C, Schlichting M, Arnaud S, Garnero P, Meunier PJ: Combined calcium and vitamin D3 supplementation in elderly women: confirmation of reversal of secondary hyperparathyroidism and hip fracture risk: the Decalyos II study. Osteoporos Int 2002, 13(3):257-264.

49. - Sanders KM, Stuart AL, Williamson EJ, Simpson JA, Kotowicz MA, Young D, Nicholson GC: Annual high-dose oral vitamin D and falls and fractures in older women: a randomized controlled trial. JAMA 2010, 303(18):1815-1822. This study demonstrates that a single annual 500,000 IU oral dose of cholecalciferol increased risk of falls and fractures, with the greatest increase occurring during the first 3 months after dosing.

50. Smith H, Anderson F, Raphael H, Maslin P, Crozier S, Cooper C: Effect of annual intramuscular vitamin $\mathrm{D}$ on fracture risk in elderly men and women-a population-based, randomized, double-blind, placebo-controlled trial. Rheumatology (Oxford) 2007, 46(12):1852-1857.

51. Ishijima M, Sakamoto Y, Yamanaka M, Tokita A, Kitahara K, Kaneko H, Kurosawa H: Minimum Required Vitamin D Level for Optimal Increase in Bone Mineral Density with Alendronate Treatment in Osteoporotic Women. Calcif Tissue Int 2009.

52. Antoniucci DM, Vittinghoff E, Palermo L, Black DM, Sellmeyer DE: Vitamin D insufficiency does not affect response of bone mineral density to alendronate. Osteoporos Int 2009, 20(7):1259 1266.

53. Antoniucci DM, Vittinghoff E, Blackwell T, Black DM, Sellmeyer DE: Vitamin D insufficiency does not affect bone mineral density response to raloxifene. J Clin Endocrinol Metab 2005, 90 (8):4566-4572.

54. Heaney RP: Functional indices of vitamin D status and ramifications of vitamin D deficiency. Am J Clin Nutr 2004, 80(6 Suppl):1706S-1709S.

55. Theiler R, Stahelin HB, Kranzlin M, Somorjai G, Singer-Lindpaintner L, Conzelmann M, Geusens P, Bischoff HA: Influence of physical mobility and season on 25-hydroxyvitamin D-parathyroid hormone interaction and bone remodelling in the elderly. Eur $\mathrm{J}$ Endocrinol 2000, 143(5):673-679.

56. Trivedi DP, Doll R, Khaw KT: Effect of four monthly oral vitamin D3 (cholecalciferol) supplementation on fractures and mortality in men and women living in the community: randomised double blind controlled trial. BMJ 2003, 326(7387):469.

57. Yates AA, Schlicker SA, Suitor CW: Dietary Reference Intakes: the new basis for recommendations for calcium and related nutrients, B vitamins, and choline. J Am Diet Assoc 1998, 98(6):699-706.

58. - Bischoff-Ferrari HA, Kiel DP, Dawson-Hughes B, Orav JE, Li R, Spiegelman D, Dietrich T, Willett WC: Dietary calcium and serum 25-hydroxyvitamin D status in relation to BMD among U.S. adults. J Bone Miner Res 2009, 24(5):935-942. In this study, 25 $(\mathrm{OH}) D$ status is more important than increasing dietary calcium intake for improving hip BMD.

59. Bischoff-Ferrari HA, Dawson-Hughes B, Baron JA, Burckhardt P, Li R, Spiegelman D, Specker B, Orav JE, Wong JB, Staehelin HB et al: Calcium intake and hip fracture risk in men and women: a meta-analysis of prospective cohort studies and randomized controlled trials. Am J Clin Nutr 2007, 86(6):1780-1790.

60. Bolland MJ, Avenell A, Baron JA, Grey A, MacLennan GS, Gamble GD, Reid IR: Effect of calcium supplements on risk of myocardial infarction and cardiovascular events: meta-analysis. BMJ 2010, 341:c3691. 